\title{
Attorney's Fees for $\$ 1983$ Claims in Fair Hearings: Rethinking Current Jurisprudence
}

\author{
Erika Geetter $\dagger$
}

Section 1983 provides a cause of action to an individual injured by any person who, acting under color of state law, deprives her "of any rights, privileges, or immunities secured by the Constitution and laws." The 1976 Attorney's Fees Awards Act ("§ 1988") provides that a court may award an individual who prevails in any action or proceeding to enforce $\S 1983$ "a reasonable attorney's fee as part of the costs."2 The language of these two statutes leads one to conclude that all individuals who prove that state officials have violated their federal rights are equally eligible to receive attorney's fees under $\S 1988$. This conclusion, however, is incorrect.

Consider the following situation: A woman residing in New York City receives notice that the local social service agency is terminating her benefits under Aid to Families with Dependent Chil-

$\dagger$ B.A. 1985, Yale University; J.D. Candidate 1989, The University of Chicago.

42 USC § 1983 (1982) provides:

Every person who, under color of any statute, ordinance, regulation, custom, or usage, of any State or Territory or the District of Columbia, subjects, or causes to be subjected, any citizen of the United States or other person within the jurisdiction thereof to the deprivation of any rights, privileges, or immunities secured by the Constitution and laws, shall be liable to the party injured in an action at law, suit in equity, or other proper proceeding for redress. For the purposes of this section, any Act of Congress applicable exclusively to the District of Columbia shall be considered to be a statute of the District of Columbia.

242 USC \& 1988 (1982) provides in relevant part:

In any action or proceeding to enforce a provision of sections 1981, 1982, 1983, 1985, and 1986 of this title, title IX of Public Law 92-318 [20 U.S.C. 1681 et seq.], or title VI of the Civil Rights Act of 1964 [42 U.S.C. 2000 d et seq.], the court, in its discretion, may allow the prevailing party, other than the United States, a reasonable attorney's fee as part of the costs.

Though the Act appears to apply equally to plaintiffs and defendants, the Senate, following case law interpreting the fee shifting provisions of Title VII, intended that a successful plaintiff receive fees as a matter of course, but that a defendant receive fees only when the plaintiff's suit is "clearly frivolous, vexatious, or brought for harassment purposes." The Civil Rights Attorney's Fees Awards Act of 1976, S Rep No 94-1011, 94th Cong, 2d Sess 5 (1976) ("Senate Report") reprinted in 1976 USCCAN 5908, 5912. 
dren ("AFDC"). ${ }^{3}$ The notice informs her that she is entitled to a fair hearing to contest the termination and to representation at such a hearing. The woman, feeling that she cannot adequately represent herself at a hearing, seeks an attorney who might be willing to help.

The attorney with whom she speaks researches her case and decides that the agency has violated the federal Social Security Act. The attorney tells the woman that under current law she has two options. First, she can bring an action in federal district court or state court under 42 USC $\S 1983$, claiming that the agency's action deprived her of a right secured by the laws of the United States. If she wins she will almost certainly get attorney's fees under $\S 1988$. Second, she can make the same claim in an optional administrative fair hearing to be conducted by a state hearing examiner. If she wins, however, she will not get attorney's fees. The attorney tells the woman that, given the speed of the hearing and its simplified procedures, the second option would probably be in her best interest, and that she has a very strong case, but that he cannot represent her unless assured of fees.

The foregoing dilemma arises because the Supreme Court has read $\S 1988$ to bar fees for parties who prevail in optional administrative proceedings. Though the Court has not ruled directly on the applicability of $\S 1988$ to $\S 1983$ claims raised in administrative fair hearings, a reading of the Supreme Court's decisions on attorney's fees for other types of optional administrative proceedings strongly suggests that it would rule against such an award. The Court has distinguished between mandatory administrative proceedings under Title VII and optional administrative proceedings under the statutes covered by $\S 1988$, allowing fees in the former, but disallowing fees in the latter. In addition, the Court, on procedural grounds, has refused to allow plaintiffs who prevail in optional administrative proceedings to bring a separate action for fees. This creates yet another barrier to fee recovery.

Using the proceedings developed by New York State as an example, this comment examines the question of whether state administrative proceedings to enforce welfare benefits extended under federal law should be considered "proceedings to enforce $\S$ 1983 " and hence lead to an award of attorney's fees under $\S 1988$. Though the comment focuses on proceedings to enforce AFDC benefits, the arguments it advances also apply to other federal-

3 Aid to Families with Dependent Children, The Social Security Act of 1935, Title IVA, 42 USC $\S 601$ et seq (1982). 
state programs that require states to hold hearings in conjunction with the distribution of funds. ${ }^{4}$

This comment argues that in the case of federally mandated fair hearings, the Supreme Court should rethink its jurisprudence barring fees for optional administrative proceedings. Alternatively, Congress should remedy the Supreme Court's jurisprudence by amending those statutes that require fair hearings to make it clear that fees are available under $\S 1988$ to parties who prevail on $\S$ 1983 claims in such hearings. Section I of the comment first demonstrates that, in certain cases, fair hearings conducted under grant-in-aid programs such as AFDC constitute "proceedings to enforce $\S 1983$ " and fall within the language of $\S 1988$. It then sets forth the mechanics of fee recovery for successful fair hearing participants. Section II of the comment examines the Supreme Court's jurisprudence regarding the award of attorney's fees for administrative proceedings, specifically discussing the way in which the Court has differentiated between administrative proceedings under Title VII and those under the statutes covered by $\S$ 1988 such as $\S 1983$. Sections III and IV argue that this differentiation is unwarranted and that, although AFDC fair hearings are optional, individuals who choose fair hearings over court actions should still be entitled to fee awards under $§ 1988$.

\section{A Framework for Fee Awards in AFDC Fair Hearings}

In Maine $v$ Thiboutot, ${ }^{5}$ the Supreme Court upheld a welfare recipient's right to bring suit against the state under $\S 1983$ claiming that the state's decision to change the way it computed AFDC benefits violated the Social Security Act. The Court found that the words "and laws" in the language of $\S 1983$ meant "that the $\S 1983$ remedy broadly encompasses violations of federal statutory as well as constitutional law."' Though subsequent cases limit the extent to which $\S 1983$ provides private plaintiffs a cause of action to enforce federal statutes, ${ }^{7}$ they do not cast doubt on the existence of a

- For instance, the analysis would apply to benefits extended under Medicaid, 42 USC $\S 1396$ et seq (1982), or the Food Stamps Act of 1977,7 USC $\S 2011$ et seq (1982).

s 448 US 1 (1980).

Id at 4 .

? The broad language of Thiboutot, sanctioning private causes of action under $\S 1983$ for public rights, was modified one year later in Pennhurst State School and Hosp. $v$ Halderman, 451 US I (1981) (if a statute merely requires a state to provide assurance to a federal agency that it is complying with that statute, but does not confer substantive rights on individuals, then there is no cause of action under $\$ 1983$ to enforce the statute), and Middlesex County Sewerage Authority v National Sea Clammers Association, 453 US 1 (1981) 
private right of action under $\S 1983$ for beneficiaries of funds under the Social Security Act. ${ }^{8}$

Plaintiffs who prevail in "actions or proceedings to enforce $\S$ 1983 " are entitled to receive attorney's fees under 42 USC $\S 1988 .{ }^{\circ}$ The Thiboutot Court made clear that those who prevail in § 1983 suits brought to enforce federal statutes such as the Social Security Act are entitled to fees just as those who prevail on constitutional claims. ${ }^{10}$ Though Thiboutot settled the question of the use of $\S$ 1983 and $\S 1988$ in court cases to enforce the Social Security Act, it did not answer the question of whether adjudicatory proceedings conducted by state agencies administering grant programs under the Social Security Act constitute "proceedings to enforce § 1983" within the meaning of $\S 1988$. AFDC, the federal statute at issue in Thiboutot, provides a good test case for answering this question, and New York State's fair hearings exemplify the type of administrative proceedings that states conduct under AFDC.

\section{A. The AFDC Program}

AFDC, a grant program established by the Social Security Act of 1935 , enables states to aid needy children who have been deprived of parental support either because their fathers are unemployed or absent from home continuously, or their mothers are ab-

(no cause of action under $\$ 1983$ for alleged violation of the Federal Water Pollution Control Act and Marine Protection Research and Sanctuaries Act because statutes in question had comprehensive enforcement mechanisms). For a discussion of the effect of these two cases on Thiboutot, see Note, Making the Old Federalism Work: Section 1983 and the Rights of Grant-in-Aid Beneficiaries, 92 Yale L J 1001 (1983); Cass R. Sunstein, Section 1983 and the Private Enforcement of Federal Law, 49 U Chi L Rev 394 (1982).

s The availability of a $\$ 1983$ action against states or state officials acting in their official capacity is limited by state sovereign immunity under the Eleventh Amendment to suits in federal court. In Edelman v Jordan, 415 US 651 (1974), the Supreme Court held that neither $\$ 1983$ nor participation in a federally funded program acts as a waiver of state sovereign immunity. Therefore, an order requiring state officials to pay retroactive benefits to persons denied such benefits under invalid state regulations was found to violate the Eleventh Amendment. After Edelman, suits against state officials may be brought in federal court only for prospective injunctive relief. Otherwise they must be brought in state court.

"Though the language of $\S 1988$ does not actually "entitle" a plaintiff to fees, the discretion that it gives the court is, in practice, extremely narrow. Congress has mandated that a prevailing party "should ordinarily recover an attorney's fee unless special circumstances would render such an award unjust." Senate Report at 4, reprinted in 1976 USCCAN at 5912 (cited in note 2) (quoting Newman v Piggie Park Enterprises, 390 US 400, 402 (1968)). Allegations by defendants that special circumstances exist "are almost unanimously rejected by the courts." Robert W. Fioretti \& James J. Convery, Attorney's Fees: The Mushrooming Cloud of Litigation, 34 De Paul L Rev 943, 946 n 21 (1985).

${ }^{10} 448$ US at 9-10. 
sent, incapacitated, or deceased.11 In New York State, the federal government finances 50 percent of the program. ${ }^{12}$ The laws and regulations that govern the program are part federal and part state and local. The state defines the level of need for purposes of determining eligibility for the program, sets its own benefit levels, establishes certain income and resource limits, and administers the program..$^{13}$ However, the state must do all of this within limitations set by the federal government, many of which are quite specific. Among other requirements, there are federal guidelines for the maximum gross income of beneficiaries ${ }^{14}$ and limitations on countable income, ${ }^{15}$ as well as requirements for beneficiary participation in work incentive programs. ${ }^{16}$ By accepting the federal grant under AFDC, New York State has agreed to comply with all federal regulations governing the program. ${ }^{17}$

The federal government also dictates the hearing procedure that the state must provide individuals who have been denied assistance or have had aid terminated or reduced. ${ }^{18}$ Under federal regulations, these procedures, known as "fair hearings," must be before a state agency, though they may be preceded by an evidentiary hearing at the local level. ${ }^{19}$

In New York, the state Department of Social Services administers AFDC through local social services districts organized on the county level. ${ }^{20}$ Public assistance applicants or recipients have

11 House Committee on Ways and Means, Background Material and Data on Programs within the Jurisdiction of the Committee on Ways and Means, 99th Cong, 2d Sess 354 (1986).

12 Id at 383 .

1342 USCA \& 602(a)(7)(1988).

1442 USCA $\$ 602(\mathrm{a})(18)(1988)$.

15 42 USCA $\$ 602(\mathrm{a})(8)(\mathrm{A})(1988)$.

26 42 USCA \& 602(a)(19)(1988).

17 The Social Security Act creates a "federally imposed obligation [on the States] to furnish 'aid to families with dependent children ... with reasonable promptness to all eligible individuals." "King $v$ Smith, 392 US 309, 333 (1968) (quoting the Social Security Act). See also, Torres $v$ Perales, 121 App Div 2d 386, 388, 503 NYS2d 96 (1986) ("Federal law requires a state which adopts the AFDC program to provide benefits to all eligible persons . .. and such a state may not limit eligibility to or impose restrictions on AFDC benefits in any manner which does not comport with Federal law").

18 These procedures, set out in the regulations promulgated by Health and Human Services' Office of Family Assistance pursuant to 42 USCA $\$ 602(\mathrm{a})(4)$ (1988), impose both constitutional and statutory requirements on fair hearings. They state that hearings must "meet the due process standards set forth in the U.S. Supreme Court decision in Goldberg v. Kelly, 397 U.S. 254 (1970)" and detail the situations in which a hearing must be granted as well as the rules governing the hearing itself, such as the claimant's right to examine contents of the case file or bring witnesses. 45 CFR 205.10(a)(1-5) (1987).

19 45 CFR 205.10(a)(1) (1987).

${ }^{20}$ NY Social Services Law, Art II, §§ 17, 20, 34 (McKinney 1983). New York divides up 
the right to contest local social service officials' decisions on whether to grant, discontinue, or reduce assistance. These challenges take place in a fair hearing before the state commissioner. ${ }^{21}$

The federal regulations do not limit the type of claims that a state may entertain in fair hearings. The federal Department of Health and Human Services ("HHS"), which administers the program, clearly contemplated that at times claimants would seek hearings not only to demand their entitlement to benefits under a valid state law, but also to contest the validity of the state's policies, laws, or regulations under federal law. ${ }^{22}$ New York State's regulations permit fair hearings upon denial or discontinuation of grants and upon "any other grounds affecting the applicant or recipient's entitlement to assistance or the amount thereof or the time of payment thereof . . ..."23

\section{B. Fee Generating Claims in Fair Hearings}

Only those claims advanced in fair hearings that can be characterized as claims to enforce $\S 1983$ would give rise to fees under $\S$ 1988. Hence, certain claims will not generate fees. ${ }^{24}$ For instance, claims involving pure issues of fact under the applicable state law or regulation are not $\S 1983$ actions and will not give rise to fees. ${ }^{25}$

grant administration among 57 counties and New York City. Characteristics of State Plans for Aid to Families with Dependent Children under the Social Security Act, Title IV-A 201, 205 (HHS, 1986).

${ }^{21} 18$ NYCRR § $358.2(f)(1983)$. Section 1983 actions cannot be raised against officials who administer programs that are wholly federally funded, for such officials do not act "under color of state law." Ellis v Blum, 643 F2d 68, 83 (2d Cir 1981). However, the Second Circuit has held that officials who administer programs whose costs are shared by state and federal governments act "under color of state law." Rose v Heintz, 806 F2d 389 (2d Cir 1986). If plaintiffs prevail in such actions they are entitled to fees under $\S 1988$. Id at 391.

${ }^{22}$ The regulations stipulate that, at the discretion of the state, a hearing may be denied "when either State or Federal law requires automatic grant adjustments for classes of recipients unless the reason for an individual appeal is incorrect grant computation." 45 CFR $205.10(a)(5)(1987)$. If a state does decide to hold a hearing when "the sole issue is one of State or Federal law or policy, or change in State or Federal law" then the regulations provide that the agency may discontinue benefits before a fair hearing decision is rendered. 45 CFR 205.10(a)(6)(1987).

${ }^{23} 18$ NYCRR § 358.4(a)(6)(1986).

24 For a suggestion of the way to categorize the type of issues that might be brought up in a fair hearing, see Laura Cooper, Goldberg's Forgotten Footnote: Is There a Due Process Right to a Hearing Prior to the Termination of Welfare Benefits When the Only Issue Raised Is a Question of Law?, 64 Minn L Rev 1107 (1980). In a study of Minnesota fair hearings, Cooper shows that issues of law (including interpretation, conflict between state and federal law, and unconstitutionality) arise in a substantial number of fair hearings.

${ }^{25}$ An example of an issue of fact is whether a recipient is "unemployable by virtue of a 'medically determined physical or mental impairment.'" Collins v D'Elia, 104 App Div 1035, 480 NYS2d 948 (1984). 
Neither will claims that a local official's policy conflicts with a substantive provision of state law or state regulations, or that the state regulations violate state law. In such cases, where the state has discretion to determine entitlements, there is no deprivation of a federally guaranteed right.

Other claims raised at fair hearings, however, do provide a basis for a $\S 1983$ action. First, one could claim that a local official's interpretation of the Social Security Act or federal regulations or his policy decision or rule violated that act, the federal regulations, or the Constitution. ${ }^{26}$ Second, one could claim that a state regulation promulgated by the Social Services Department violated the Social Security Act, a federal regulation, or the Constitution. ${ }^{27} \mathrm{Fi}$ nally, one could claim that a state law violated the Social Security Act, a federal regulation, or the Constitution. ${ }^{28}$

If a claimant had decided to forgo a fair hearing and had won on any of the above claims in a state or federal court action, fees would be awarded under $\S 1988$. However, the claimant who decides to use the fair hearing mechanism and who prevails cannot recover fees. This is true despite the similarity of $\S 1983$ claims in fair hearings and court actions.

The Supreme Court cases that bar fee awards in administrative fair hearings will be discussed in section II and criticized in sections III and IV. Absent these bars, however, fee awards for fair hearings could easily be modeled on those for court actions. For instance, an AFDC participant could win either at the fair hearing itself or in a court action on appeal of an adverse determination at the hearing. In the former case, the claimant would bring a separate action to recover fees from the county official against whom

${ }^{28}$ See Stark v Wyman, 59 Misc 2d 504, 506, 299 NYS2d 686 (Sup Ct 1969), in which an AFDC recipient challenged the New York City Department of Social Service's decision to deny her an increased food allowance to purchase kosher food as a violation of equal protection and a denial of freedom of religion.

${ }^{27}$ See Reid v Toia, 72 App Div 2d 465, 468, 424 NYS2d 964 (1980), in which the court found that subdivision (b) of section 352.26 of the state regulations was invalid because it was "in conflict with the Federal Social Security Act and the HEW regulations promulgated under it." See also Johnson v Blum, 58 NY2d 454, 448 NE2d 449 (1983), where the court found that the State Commissioner's administrative directive that differentiated recipients from applicants for the purposes of determining whether parents are obligated to dispose of non-essential assets violated the Equal Protection Clause of the Constitution.

${ }^{28}$ See Blake v Berger, 85 Misc 2d 865, 380 NYS2d 575 (Sup Ct 1976), in which petitioners claimed (though they did not prevail) that New York Social Services Law $\S 321$ and 322 , which allowed termination of benefits solely because of a recipient's refusal to execute a mortgage on real property, violated the Social Security Act by imposing additional and unauthorized eligibility standards for AFDC qualification. 
she prevailed in the fair hearing. ${ }^{29}$ This action could be brought either in state or federal court..$^{30}$

If the claimant loses at the fair hearing, she could appeal the decision to the state court ${ }^{31}$ or she could bring a $\S 1983$ action in federal district court based on the same underlying claim. ${ }^{32}$ If she wins in state or federal court, fees would be awarded against the state commissioner pursuant to $\S 1988$ not only for the time spent on the court action, but for the time expended on $\S 1983$ claims in the fair hearing as well. ${ }^{33}$

28 In Monell v Department of Social Services, 436 US 658 (1978), the Court held that local governmental bodies, which includes counties, are persons under $\$ 1983$ and can be sued directly for declaratory and injunctive relief. Furthermore, local governmental officials may be sued in their official capacities for such relief. This means that the court can assess attorney's fees against such officials in their official capacities. See Sheldon H. Nahmod, Civil Rights and Civil Liberties Litigation: The Law of Section 198357 (Shepard's/McGraw Hill, 2d ed 1986).

30 In Martinez $v$ California, 444 US 277, 283 (1980), the Court noted that the states have concurrent jurisdiction over $\$ 1983$ claims. In Thiboutot, 448 US 1, the Court held that state courts are authorized to award fees under $\S 1988$. The New York Court of Appeals reiterated the Thiboutot holding in Johnson $v$ Blum, 58 NY2d 454, 457-458, 448 NE2d 449 (1983).

${ }^{31}$ In New York, judicial review of agency action is known as an "article 78 proceeding," authorized by NY Civil Practice Law and Rules $\S 7801$ et seq (McKinney 1981) and heard by a trial level court. The scope of review under article 78 is narrow; it is limited to a substantial evidence review, an arbitrary and capricious standard, or an abuse of discretion standard, depending on the question raised. See Pietranico $v$ Ambach, $82 \mathrm{App}$ Div 2d 625, 442 NYS2d 827 (1981), affd 55 NY2d 861, 447 NYS2d 924, 432 NE2d 796 (1982). Such actions might be preferred to a federal court action, since the article 78 proceeding is procedurally much simpler.

32 Plaintiff may prefer to bring an action in state court since, under Edelman v Jordan, 415 US 651 (1974), plaintiff will not receive retroactive relief if she prevails in a suit against a state official in federal court. See note 8 . New York, however, authorizes such relief. See Schimmel v Reed, 50 App Div 2d 1085, 377 NYS2d 313 (1975), aff'd 40 NY2d 887, 389 NYS2d 361, 357 NE2d 1016 (1976).

${ }^{33}$ Though fees may be awarded in federal court for statutory $\S 1983$ cases, such awards may give rise to problems in conjunction with federal officials' immunity from retroactive relief under the Eleventh Amendment. In Hutto v Finney, 437 US 678 (1978), the Court held that Eleventh Amendment sovereign immunity will not shield federal officials from paying attorney's fees to plaintiffs who succeed in federal court $\S 1983$ actions brought to vindicate constitutional rights. Hutto did not examine the Eleventh Amendment issue in the context of statutory-based $\S 1983$ claims, and the Court specifically declined to reach the issue in Maher v Gagne, 448 US 122, 130 (1980). One possible basis for the Court's decision in Hutto was its finding that in passing $\S 1988$, Congress was exercising its power under $\S 5$ of the Fourteenth Amendment to set aside the states' immunity from retroactive relief. 437 US at 639 . Under this reading of Hutto, when $\S 1983$ claims are brought to enforce statutory and not constitutional rights, Congress may not have waived the states' Eleventh Amendment immunity. See Thiboutot, 448 US at $9 \mathrm{n}$ 7. Alternatively, if the basis for the Court's decision was that fees should be regarded simply as "costs," then the Eleventh Amendment does not bar a fee award even in statutory-based claims, for costs do not constitute retroactive relief, but are rather a reimbursement to the plaintiff "for a portion of the expenses he incurred in seeking prospective relief." 437 US at 695 n 24 . One commentator 


\section{Fee Awards for Multiclaim Fair Hearings}

Claimants who only raise and prevail on claims under the Social Security Act or the Constitution present the clearest case for allowing fees under $\S 1988$. However, at many AFDC hearings, claimants may raise more than one claim. For instance, a claimant may allege that the department's actions violated both the state and federal social security laws, ${ }^{34}$ or that the department violated a state statute as well as a constitutionally guaranteed right of due process or equal protection under the Fourteenth Amendment. ${ }^{36}$

Under current law, if such a claimant had decided to forgo a hearing and had brought multiple claims in court, fees could be awarded under $\S 1988$ even if the case were decided simply on state law grounds. ${ }^{36}$ The law governing fee awards in multiclaim court litigation grew out of language in the House Report accompanying $\S 1988,{ }^{37}$ which the courts subsequently applied in deciding such cases. The reasoning that applies to multiclaim court actions could be extended to allow fees for multiclaim fair hearings.

\section{Fee claims based on statutory violations.}

The House Report first sets forth the rule governing fee awards for cases in which a plaintiff joins a non-fee claim with a statutory-based $\S 1988$ claim. ${ }^{38}$ It states: "To the extent a plaintiff joins a claim under one of the statutes enumerated in H.R. 15460 [§ 1988] with a claim that does not allow attorney fees, that plaintiff, if it prevails on the non-fee claim, is entitled to a determination on the other claim for the purpose of awarding counsel fees."ss

This rule could be applied to fair hearings as well. For instance, suppose a claimant raises both a state law and a statutory $\S$

has argued that even if the holding of Hutto was based on Congress's Fourteenth Amendment enforcement powers, the Eleventh Amendment should still not bar fees for statutory $\S$ 1983 claims. See Comment, Civil Rights Attorney's Fees in Cases Resolved on State Pendent and Federal Statutory Grounds, $130 \mathrm{U}$ Pa L Rev 488, 507-512 (1981).

34 See, for example, Reid v Toia, 72 App Div 2d 465. 1969).

${ }^{3 s}$ See, for example, Stark $v$ Wyman, 59 Misc 2d 504, 505, 299 NYS2d 686 (Sup Ct

${ }^{36}$ For a discussion of the permutations of multiclaim litigation, see Arthur D. Wolf, Pendent Jurisdiction, Multi-Claim Litigation, and the 1976 Civil Rights Attorney's Fees Awards Act, 2 W New Eng L Rev 193 (1979).

${ }^{37}$ The Civil Rights Attorney's Fees Awards Act of 1976, HR Rep 94-1558, 94th Cong, 2d Sess 4 n 7 (1976) ("House Report") reprinted in Civil Rights Attorney's Fees Awards Act of 1976, Source Book: Legislative History, Texts, and Other Documents, 94th Cong, 2d Sess, Committee Print 209, 212 ("Source Book").

${ }^{38}$ This would include statutory $\S 1983$ claims based on the Social Security Act.

so House Report at $4 \mathrm{n} \mathrm{7,} \mathrm{reprinted} \mathrm{in} \mathrm{Source} \mathrm{Book} \mathrm{at} 212$ (cited in note 37). 
1983 claim in a fair hearing, and the examiner awards relief only upon finding a violation of the state welfare law. For the purposes of the fee award, the court awarding fees would have to determine whether the action in question also violated the federal act. ${ }^{40}$ If plaintiffs are not entitled to such a determination, they may be discouraged from bringing meritorious state statutory non-fee claims at the hearing out of concern that such claims will provide the basis for the hearing officer's decision. If such claimants lose in the fair hearing, they may be barred by the state's appellate rules from raising those non-fee claims in state court on appeal, ${ }^{41}$ and by the Eleventh Amendment from bringing them as pendant claims in a subsequent federal court action. ${ }^{2}$

\section{Fee claims based on constitutional violations.}

Another rule in the House Report involves the situation in which a non-fee claim is joined with a constitutional fee-generating claim. The House Report notes:

In some instances, however, the claim with fees may involve a constitutional question which the courts are reluctant to resolve if the non-constitutional claim is dispositive. Hagans $v$. Lavine. In such cases, if the claim for which fees may be awarded meets the "substantiality" test, see Hagans v. Lavine, United Mine Workers v. Gibbs, attorney's fees may be allowed even though the court declines to enter judgment for the plaintiff on that claim, so long as the plaintiff prevails on the non-fee claim arising out of a "common nucleus of operative fact." United Mine Workers v. Gibbs. ${ }^{43}$

10 The determination would be the same if the claimant prevailed on appeal from an adverse decision at the fair hearing.

${ }^{11}$ Article 78 proceedings are limited to review of the issues presented in fair hearings. See note 31 .

12 In Pennhurst State School and Hosp. v Halderman, 465 US 89, 97-124 (1984), the Court held that federal courts have no jurisdiction over state law claims seeking injunctive relief against state officials regardless of the federal court's original basis for subject matter jurisdiction. Thus, pendent jurisdiction is not a basis for extending federal jurisdiction over such state law claims.

${ }^{43}$ House Report at $4 \mathrm{n} 7$ (citations omitted), reprinted in Source Book at 212 (cited in note 37). In Hagans v Lavine, 425 US 528 (1974), the "substantiality" test was used to determine whether a constitutional claim was sufficient to confer jurisdiction on a district court hearing a group of federal and non-federal claims. In order for jurisdiction to be appropriate, the case must present a claim that is not "wholly insubstantial" or "obviously frivolous." Id at 537. In United Mine Workers v Gibbs, 383 US 715 (1966), the requirement that state and federal claims "derive from a common nucleus of operative fact" was used as part of the test for determining when a federal court has the power to hear pendent state 
In Maher $v$ Gagne, ${ }^{44}$ the Supreme Court applied the language in the House Report to award fees in a $\S 1983$ suit in which the plaintiff alleged that the state's AFDC regulations violated the Social Security Act as well as the Equal Protection and Due Process Clauses of the Fourteenth Amendment. ${ }^{45}$ Although the plaintiff's constitutional claim was never adjudicated (the case was settled by consent decree), the court found that it met the substantiality test of Hagans $v$ Lavine and awarded fees based on that claim. ${ }^{46}$

Suppose that, in an AFDC fair hearing, a claimant challenges the county's decision to withdraw benefits because of her alleged cohabitation with a man other than her husband. The claimant argues both that state "substitute father" regulations ${ }^{47}$ violate the Equal Protection Clause and that she is not in fact engaged in an ongoing illicit relationship. She presents testimony on both claims and asks under each that her benefits be restored. She prevails on the factual issue and the constitutional claim is not reached. Under the Hagans and Gibbs test and Maher holding, fees would be awarded because the constitutional claim was "substantial" and both claims arose from a "common nucleus of operative fact." 48

In Smith v Robinson, ${ }^{49}$ the Court restricted the scope of the Hagans test relied on in Maher, holding that a plaintiff seeking to recover fees "may not rely simply on the fact that substantial feegenerating claims were made during the course of the litigation." The Court held that if the unadjudicated constitutional claim was based on facts and legal theories different from those underlying the non-fee claim, and particularly if the constitutional claim warranted different relief, it could not be the basis of a fee award. ${ }^{\text {s1 }}$

claims. Id at 725. One should note that for purposes of $\S 1988$, the Hagans and Gibbs tests are not used to determine jurisdiction, but only act as a rule for the courts to apply when awarding fees in multiclaim litigation involving federal constitutional issues.

4448 US 122 (1980).

4s Id at $133 \mathrm{n} 15$.

6 Though the plaintiff's statutory $\S 1983$ claim would have supported a fee award under Thiboutot as well, the court chose to base the fee award on the constitutional claim in order to avoid any Eleventh Amendment difficulties. See note 33.

47 Under substitute father regulations (invalidated in King $v$ Smith, 392 US 309 (1968)), AFDC payments were denied "to the children of a mother who 'cohabits' in or outside her home with any single or married able-bodied man." Id at 311. For purposes of benefits, the man was considered to be the "substitute father" of all the mother's children, regardless of whether he was legally obligated to support them or contributed to their support. Id at 314.

48 See note 43 and accompanying text.

468 US 992 (1984).

so Id at 1007.

${ }^{51} \mathrm{Id}$ at 1015. 
The impact of Smith is unclear. Congress overturned its specific statutory holding, ${ }^{\mathrm{52}}$ and it is uncertain how Smith's test for fee awards would apply to different fact patterns. For the hypothetical claimant discussed above, fees would be awarded if the court focused on the similarity of the relief requested, but denied if it focused on the different legal theories behind the claims. ${ }^{53}$ Given this uncertainty, claimants with strong constitutional claims can only guarantee fee recovery by raising those claims in a separate proceeding. In practice, this phenomenon, plus the superior expertise of courts in constitutional matters, will ensure that most claimants continue to bring constitutional claims in courts rather than at fair hearings.

\section{- II. Supreme Court Decisions on Attorney's Fees for Administrative Proceedings}

Though the scheme described above could be used to award attorney's fees for fair hearings to claimants who ultimately prevail, the Supreme Court's jurisprudence regarding the award of attorney's fees for administrative proceedings makes it unlikely that any such awards will be granted. This section discusses the three major Supreme Court cases that have developed this jurisprudence: New York Gaslight Club, Inc. v Carey, ${ }^{54}$ Webb v Dyer County Bd. of Ed. , ${ }^{\mathrm{ss}}$ and North Carolina Dept. of Transp. $v$ Crest

${ }^{32}$ In Smith v Robinson, the Court disallowed attorney's fees to parties who prevail in actions to enforce the Education of the Handicapped Act ("EHA"), 20 USC $\$ 1400$ et seq (1982). In response to this decision, Congress passed the Handicapped Children's Protection Act of 1976 ("HCPA"), Pub L No 99-372, 100 Stat 796, codified at 20 USCA § 1415 (Supp 1988), which gave courts the power to award attorney's fees to parties who prevail in administrative and court proceedings to enforce the EHA.

ss Before Smith $v$ Robinson, a fear that the Gibbs standard would allow fees for too many unlitigated constitutional claims prompted the Eighth Circuit in Dernheim $v$ Hennepin, 524 F Supp 1321 (D Minn 1981), affd 688 F2d 66 (8th Cir 1982), to deny fees for administrative proceedings. In Dernheim, plaintiffs contested suspension of a foster family home license on constitutional and state statutory grounds. The court wrote:

The administrative agency applicable in a particular case may deal with a much different array of issues. For example, in the instant case the issue decided by the state hearing examiner involved sufficiency of the evidence tending to show whether the plaintiffs were unfit to be foster parents. The issue in a section 1983 lawsuit would have been whether the plaintiffs had a property or liberty right in their FFH license and, if so, whether the county had complied with the requirements of the due process clause. Although the same nucleus of facts are involved, the issues presented are much different.

524 F Supp at 1324.

B4 447 US 54 (1980).

s5 471 US 234 (1985). 


\section{Street Community Council, Inc..$^{58}$}

\section{A. Title VII Proceedings: New York Gaslight Club, Inc. v Carey}

The Court's first case on the availability of fees for administrative proceedings was Carey, a suit brought under Title VII of the Civil Rights Act of $1964 . .^{57}$ Title VII, which contains its own attorney's fees provision, ${ }^{58}$ is one of the few Civil Rights statutes that require a plaintiff to exhaust administrative remedies before bringing an action in federal district court. ${ }^{69}$ The remedial scheme of Title VII requires the Equal Employment Opportunity Commission ("EEOC"), the federal agency that handles Title VII complaints, to defer all complaints brought against private employers or state and local governments to state or local fair employment practice agencies. ${ }^{80}$ This deferral system reflects Congress's attempt to ensure that the federal government, in taking charge of employment practices, would not usurp regulatory functions traditionally left to the states. ${ }^{\text {I1 }}$

Carey concerned an employment discrimination claim brought under Title VII. As required by section 706(c) of that title, ${ }^{62}$ the EEOC referred the respondent's complaint to the appropriate New

se 479 US 6 (1986).

${ }^{87} 42$ USC $\S 2000$ e et seq (1982).

ss 42 USC $\$ 2000 \mathrm{e}-5(\mathrm{k})(1982)$ provides:

In any action or proceeding under this subchapter the court, in its discretion, may allow the prevailing party, other than the Commission or the United States, a reasonable attorney's fee as part of the costs, and the Commission and the United States shall be liable for costs the same as a private person.

so There is no similar requirement that the plaintiff exhaust state judicial remedies, presumably because state court proceedings will rarely be over within 60 days of the complaint's filing, the point at which the Equal Employment Opportunity Commission has jurisdiction over the complaint. See Andrea Catania, State Employment Discrimination Remedies and Pendent Jurisdiction under Title VII: Access to Federal Courts, $32 \mathrm{Am}$ U L Rev 777, 819 (1983).

${ }^{80}$ These agencies, called 706 agencies (since they are mentioned in Section 706 of Title VII), are listed in the EEOC regulations at 29 CFR $\$ 1601.74$ (1987). A complainant who resides in a location that has a 706 agency must file his complaint first with that agency and may not file with the EEOC until 60 days after proceedings with the state commission have commenced unless these proceedings are terminated earlier. If a complainant mistakenly files with the EEOC, the commission will send the complaint to the 706 agency and hold its own complaint in "suspended animation" until the 60 day period is up. See Love v Pullman Co., 404 US 522, 526 (1972). According to the BNA Labor Relations Report, 8a Fair Employment Practices Manual 451:1 (1987), more than 60 percent of complaints received by the EEOC each year are deferred under this scheme.

61 This deferral period was also designed to ensure that "states and localities be afforded every opportunity to resolve ... difficult problems of racial justice by means of their own agencies and instrumentalities." 110 Cong Rec 12724-25 (June 4, 1964).

${ }^{82} 42$ USC \& 2000e-5(d) (1982). 
York administrative agency. While the state action was pending, the respondent, after receiving a right to sue letter from the EEOC, filed a complaint in district court. The respondent prevailed at the administrative level, and the Appellate Division of the New York Supreme Court ultimately upheld the decision of the State Human Rights Appeals Board. Pursuant to an agreement between the parties, the district court action was dismissed except for the respondent's request for attorney's fees. The district court denied the fee request, but the Second Circuit Court of Appeals reversed, holding that "[a] complaining party who is successful in state administrative proceedings after having her complaint under Title VII referred to a state agency in accordance with the statutory scheme of that Title is entitled to recover attorney's fees in the same manner as a party who prevails in federal court." ${ }^{\text {"63 }}$

The Supreme Court upheld the court of appeals. It based its reasoning on two considerations. The first was the language of the attorney's fees provision itself. The Court noted that "[ $[\mathrm{t}] \mathrm{he}$ words of $\S 706(\mathrm{k})$ leave little doubt that fee awards are authorized for legal work done in 'proceedings' other than court actions. Congress's use of the broadly inclusive disjunctive phrase 'action or proceeding' indicates an intent to subject the losing party to an award of attorney's fees and costs that includes expenses incurred for administrative proceedings." 64

Second, the Court noted that under Title VII's comprehensive enforcement scheme, resort to state and local remedies is mandatory, and that plaintiffs may file suit in federal district court only if the state does not provide prompt or complete relief..$^{65}$ The Court apparently concluded that it would be unfair to deny a plaintiff fees after forcing her to exhaust administrative remedies.

In Carey, the Court made it clear that fee requests of plaintiffs who prevail in private sector Title VII administrative proceedings should ordinarily be granted. Lower courts prior to Carey had already allowed attorney's fees for Title VII administrative proceedings involving federal employees. ${ }^{68}$ Since Carey, lower courts have

${ }^{63} 598$ F2d 1253, 1260 (2d Cir 1979).

B4 447 US at 61 . Other attorney's fees provisions do not include any reference to "proceedings." See, for example, $\S 204$ (b) of Title II, 42 USC $\$ 2000 \mathrm{a}-3(\mathrm{~b})$ (1982) and $\S 7$ of the Age Discrimination in Employment Act of 1967, 29 USC $\$ 626(\mathrm{~b})(1982)$, which incorporates the fee provisions of $\S 16$ of the Fair Labor Standards Act, 29 USC $\S 216(\mathrm{~b})$ (1982).

65447 US at 65 .

${ }^{68}$ Fees were awarded in Hammond $v$ Balzano, $10 \mathrm{Empl}$ Prac Dec (CCH) $\$ 10333$ (D DC 1975); McMullen v Warner, 416 F Supp 1163, 1167 (D DC 1976); Reyes $v$ Mathews, 428 F Supp 300, 302 (D DC 1976); Parker v Califano, 561 F2d 320, 332-333 (DC Cir 1977); Foster 
allowed fees for public and private plaintiffs proceeding under Title VII. ${ }^{67}$

\section{B. $\S 1983$ Proceedings: Webb v Dyer County Bd. of Ed.}

The language governing the award of attorney's fees under $\S$ 1988 is essentially identical to that of Title VII. ${ }^{88}$ While there is no evidence that Congress considered the issue of attorney's fees in the context of administrative proceedings, the legislative history of $\S 1988$ makes it clear that Congress sought to model it after Title VII and to apply the law that had grown up around Title VII to fee petitions brought under $\S 1988 .{ }^{69}$ In the area of fee awards for administrative proceedings, however, the Court has not applied the same rules to fee shifting under the two statutes.

Fee awards under $\S 1988$ for administrative proceedings to enforce $\S 1983$ are governed by Webb v Dyer County Bd. of Ed. ${ }^{70}$ and North Carolina Dept. of Transp. $v$ Crest Street Community Council, Inc. ${ }^{71}$ In Webb, the Court examined the substantive question of what constitutes "proceedings to enforce $\S 1983$." In Crest, the

$v$ Boorstin, 561 F2d 340, 343 (DC Cir 1977); Smith v Califano, 446 F Supp 530, 533-534 (D DC 1978); Brown v Bathke, 588 F2d 634, 638 (8th Cir 1978); and Fischer v Adams, 572 F2d 406, 409 (1st Cir 1978). Prior to 1978, private enforcement was the only means by which federal employees could enforce their rights under Title VII. In light of this, the DC Circuit noted in Parker that courts should be particularly willing to use fee shifting to encourage such enforcement. 561 F2d at 331. However, the Presidential Reorganization Plan 1 of 1978, 43 Fed Reg 19807 (1978), 92 Stat 3781, reprinted in 42 USCA \& 2000e-4 (1981), authorized the Attorney General or the EEOC to bring suits on behalf of federal employees, thereby making remedies for federal employees coextensive with those of other employees protected under Title VII.

67 Private employees have been awarded fees under Title VII in Bennett $v$ Central Telephone Co. of Ill., 619 F Supp 640,645 (N D Ill 1985) (fees allowed for proceeding before Illinois FEP Commission) and Lenihan v City of New York, 640 F Supp 822, 830 (S D NY 1986) (fees allowed for proceedings before Commission on Human Rights and EEOC). In Sullivan v Com. of Pa. Dept. of Labor, Etc., 663 F2d 443, 445-446 (3d Cir 1981) and Chrapliwy v Uniroyal, Inc., 670 F2d 760, 763 (7th Cir 1982), the court awarded fees when the concurrently filed court action served as a catalyst that enabled the plaintiff to prevail in administrative proceedings.

* Compare the text of $\S 1988$ (cited in note 2) with that of Title VII's attorney fee provision (cited in note 58 ).

6s See Statement of Rep. Drinan at 122 Cong Rec 35,122 (Oct 1, 1976); Senate Report at 4-5, reprinted in 1976 USCCAN at 5911-5912 (cited in note 2); House Report at 8, reprinted in Source Book at 216 (cited in note 37); Hensley $v$ Eckerhart, 461 US 424, 433 n 7 (1983). The legislative history of $\S 1988$ contains no mention of administrative proceedings. Passage of the bill was preceded by very little debate as both the House and Senate rushed to pass it before the end of the session. See Comment, $130 \mathrm{U} \mathrm{Pa}$ L Rev at $495 \mathrm{n} 34$ (cited in note 33 ).

${ }^{70} 471$ US 234 (1985).

${ }^{71} 479$ US 6 (1986). 
Court examined the procedural question of whether a separate suit could be brought in federal court solely to request attorney's fees.

In $W e b b$, the Court disallowed fees for state administrative proceedings prior to a $\S 1983$ action upon finding that the proceedings did not advance the $\S 1983$ litigation in court. The plaintiff, a black schoolteacher with tenure, was dismissed from his job without notice. After his dismissal, he sought a hearing, guaranteed to him by Tennessee state law, before the Dyer County School Board. He appeared with his attorney at several Board hearings and alleged both that the Board had failed to follow proper procedures before dismissing him and that his dismissal was racially motivated. After a series of hearings, the Board refused to reinstate him. Webb then filed an action in federal district court alleging violations of $\S \S 1981,1982,1983$, and 1985 . The case was settled by a consent decree under which Webb received damages and was reinstated to his job. He received attorney's fees for the time his attorney spent on the court action, but was denied fees for his attorney's time in administrative proceedings. The court of appeals affirmed the denial of fees.

Webb advanced two theories before the Supreme Court in support of his fee request: 1) that the hearings constituted "proceedings to enforce $\S 1983$ " within the meaning of $\S 1988$, and 2) that the time spent in the hearings was time reasonably expended in preparation for the court action and therefore compensable under the rule of Hensley $v$ Eckerhart. ${ }^{72}$ The Court dismissed Webb's first theory. It did not examine what claims Webb actually put forth in the administrative proceedings to enforce tenure rights, ${ }^{73}$ but concluded that since petitioner could have bypassed the School Board proceedings and gone directly to court with his $\$ 1983$ claim, those proceedings did not have the same integral function under $\S 1983$ that state administrative proceedings had under Title VII. ${ }^{74}$ The Court based its holding on the theory that optional proceedings cannot be "proceedings to enforce" one of the

72461 US 424 (1983). In Hensley, the Court stated that "[t]he most useful starting point for determining the amount of a reasonable fee is the number of hours reasonably expended on the litigation multiplied by a reasonable hourly rate." Id at 433 . Petitioners in Webb urged a reading of Hensley to require fees for all work "from the onset of an attorneyclient relationship ... reasonably related to the enforcement of federal civil rights." 471 US at 242. The Court stressed that the rule of Hensley only requires fees for the time that is " "reasonably expended on the litigation." "Id (emphasis in original).

${ }^{73}$ Petitioners brief shows that Webb's counsel raised both equal protection and due process objections to the discharge. Brief for Petitioners, 83-1360 at 4. But see Respondent's Brief, id at $9 \mathrm{n} 6$.

${ }^{24} 471$ US at 241, citing Smith $v$ Robinson, 468 US 992, 1011 n 14 (1984). 
statutes listed in $\S 1988$, since such proceedings are not undertaken pursuant to requirements imposed by the statutes themselves. The Court held that "the District Court's decision to deny any fees for time spent pursuing optional administrative remedies was well within the range of reasonable discretion."75

The Court also rejected Webb's second theory. It stated that the relevant question to ask in determining fee awards for optional administrative proceedings is whether the work was "both useful and of a type ordinarily necessary to advance the civil rights litigation to the stage it reached before settlement." 76 The Court acknowledged that in certain cases administrative proceedings could provide a substitute for trial preparation. If the proceedings obviated the need for out-of-court procedures, they would be compensable even though they occurred before the filing of a complaint in district court. However, it refused to find that $\S 1988$ covered preparations for the proceedings themselves. The Court concluded that "[ $t$ ] he five years of work before August 1979 [related to the administrative proceedings] were easily separated from the two years of work thereafter"77 and denied fees for the administrative proceedings in their entirety.

Prior to $W e b b$, some courts had allowed fee awards for administrative actions under $\S 1983 .^{78}$ Since $W e b b$, no court has allowed fees. ${ }^{79}$ Such refusals have several bases. In some post-Webb cases, courts denied fees because the administrative proceedings could not be characterized as proceedings to enforce $\S 1983$. For instance, in certain cases the constitutional $\S 1983$ claim arose out of a de-

75 Id at 244.

${ }^{76}$ Id at 243.

"7. Id.

${ }^{78}$ Ciechon $v$ City of Chicago, 686 F2d 511, 525 (7th Cir 1982). In Turillo v Tyson, 535 F Supp 577, 588 (D RI 1982), fees were awarded under $\S 1988$ when the plaintiff was required to exhaust EHA remedies in order to prevail on her constitutional claims under $\S 1983$.

${ }^{78}$ See, for example, Leroy v City of Houston, 831 F2d 576 (5th Cir 1987), reh denied 836 F2d 1346 (1987) and cert denied 108 S Ct 1735 (1988) (fees denied under $\S 1988$ for services performed before the Justice Department for preclearance submissions in an action to enforce voting guarantees of Fourteenth and Fifteenth Amendments, reversing lower court's fee award, 648 F Supp 537, 542 (S D Texas 1986)); McCullough v Cady, 640 F Supp 1012,1025 (E D Mich 1986) (fees denied for state administrative action claiming violation of due process rights in hearings before Michigan Department of Corrections Hearing Division); Healy v Town of Pembroke Park, 643 F Supp 1208, 1216-17 (S D Fla 1986), aff'd in part and rev'd in part 831 F2d 989 (11th Cir 1987) (policemen denied fees for administrative proceedings prior to $\S 1983$ suit against city); Lenihan v City of New York, 640 F Supp 822, 830-31 (S D NY 1986) (fees denied for proceedings under $\$ 1983$ before Article II Medical Board); Kuhns v City of Commerce City, 618 F Supp 1475, 1479 (D C Colo 1985) (police officer protesting denial of due process in termination procedure denied fees for counsel's work at state administrative level). 
nial of due process at the hearing itself. Thus it necessarily was not adjudicated in the hearing. ${ }^{80}$ In other cases, the plaintiff did not even raise the $\S 1983$ claims in the state proceedings. ${ }^{81}$ In still other cases, courts did not examine the nature of the claims, but simply held that $W e b b$ precludes an award of fees. ${ }^{82} \mathrm{~A}$ final reason courts have rejected fee petitions has been a finding that $\S 1988$ bars a plaintiff who prevailed at the administrative level from bringing a separate action for fees. ${ }^{83}$ This is the reading of $\S 1988$ that the Supreme Court adopted in North Carolina Dept. of Transp. $v$ Crest Street Community Council, Inc. ${ }^{84}$

\section{Separate Actions for Fees: North Carolina Dept. of Transp. $v$ Crest Street Community Council, Inc.}

$W e b b$ concerned a fee request by a plaintiff who was unsuccessful in administrative proceedings, but who ultimately prevailed in a court action. Therefore, the Court did not reach the question of whether $\S 1988$ allows a separate action solely for fees. In Crest, however, the Court concluded that a plaintiff who had prevailed in an earlier administrative proceeding could not bring an action in federal court solely for fees.

In Crest, respondents claimed that the North Carolina Department of Transportation's ("NCDOT") decision to build an extension of a major highway through a black neighborhood violated Title VI. ${ }^{85}$ The respondents filed a complaint with the United

${ }^{80}$ See, for example, Lenihan, $640 \mathrm{~F}$ Supp at 831 ("Those proceedings [before an Article II Medical Board] were not part of the statutory remedy for redress of a prior wrong, they were part of the wrong complained of in plaintiff's federal civil rights action") (emphasis in original); Venuti $v$ Riordan, 702 F2d 6, 9 (1st Cir 1983) (tavern owners who claimed they had been denied due process in a hearing to obtain a license could not claim that the license hearing itself was a proceeding to enforce $\S 1983$ ). These cases can be contrasted with Ciechon, 686 F2d 511 (equal protection and due process claim brought under $\S 1983$ by paramedic discharged from her job), a pre-Webb decision, in which the Court awarded fees though the due process violation occurred in the hearing itself. The court noted that the plaintiff's counsel "repeatedly raised objections to the procedures used and the evidence presented in the hearing. . . . Lack of due process was specifically raised and equal protection at least inferentially raised, thus warranting relief under 42 USC $\S 1988$." Id at 525.

81 Healy, 643 F Supp at 1216-17 (policemen denied fees for administrative proceedings in $\$ 1983$ suit against city where state proceedings involved alleged violations of state labor relations law).

${ }^{82}$ See, for example, Leroy, 831 F2d 576.

${ }^{83}$ See Blow v Lascaris, 523 F Supp 913, 917 (N D NY 1981), aff'd 668 F2d 670 (2d Cir 1982); Horacek $v$ Thone, 710 F2d 496, 499 (8th Cir 1983) (refusing to extend Carey and denying fees to attorney who represented parents in proceedings before State Department of Public Institutions).

84 479 US 6 (1986).

85 42 USC $\S 2000 \mathrm{~d}$ et seq (1982). Title VI prohibits discrimination on the basis of race, 
States Department of Transportation ("DOT") pursuant to regulations that the agency had promulgated under Title VI. ${ }^{86}$ After an investigation, the DOT made a preliminary finding of "reasonable cause" and urged the parties to enter into negotiations. These negotiations resulted in a Final Mitigation Plan which, among other things, would preserve the community church and park. When the NCDOT denied liability for attorney's fees incurred in negotiating the plan, the respondents filed suit in district court requesting fees under $\S 1988$ for 12,000 hours of counsel's time spent over a five year period of negotiations. ${ }^{87}$ The Supreme Court did not examine whether the negotiations under Title VI were "proceedings" within the meaning of $\S 1988 . .^{88}$ Instead, the Court held that a federal court may not award attorney's fees in an independent action that does not seek to enforce any of the civil rights laws listed in $\S$ $1988 .{ }^{89}$ Examining the language of $\S 1988$, the Court found that it authorized collection of fees for an action or proceeding only in "the court" that heard the action. ${ }^{90}$ Hence, the court that awards the attorney's fees must be the same court in which a complaint that includes a civil rights violation is filed.91 A plaintiff may not recover attorney's fees for proceedings in another forum even if they led to a vindication of her rights.

\section{An Argument for Fee Awards in AfDC Fair Hearings}

The Carey, Webb, and Crest decisions indicate that the Court would not allow fees for AFDC fair hearings. Specifically, the

color, or national origin, under any program receiving federal financial assistance.

${ }^{88} 49$ CFR § 21.11(b) (1987).

8749 US at 10.

${ }^{88}$ For a discussion of this question as well as of the holding in Crest, see Note, The Supreme Court's Interpretation of Section 1988 and Awards of Attorney's Fees for Work Performed in Administrative Proceedings: A Proposal for a Result-Oriented Approach, 62 Wash L Rev 889 (1987). The respondents in Crest also claimed fees as intervenors in a related suit filed by an environmental group, ECOS, Inc. After ECOS entered a consent judgment, the Crest respondents requested fees for counsel's time during their negotiations with the NCDOT. Since they had obtained, through the consent judgment, some of the relief they sought in the Title VI negotiations, the district court held that those negotiations constituted "proceedings to enforce Title VI" and awarded fees for the Crest respondent's limited success in district court. ECOS, Inc. v Brinegar, 671 F Supp 381 (M D NC 1987).

89 479 US at 12.

9o Id. One commentator has noted that the Court's conclusion from the language of the statute is grounded on "an erroneous paraphrasing of $\S 1988$." The Court paraphrased the statute's reference to "any action or proceeding" to enforce civil rights as "the action or proceeding" (emphasis added) to enforce civil rights, thus "[linking] a court's award of attorney's fees to consideration of the merits of the civil rights violation by the same court in the same action or proceeding." Note, 62 Wash L Rev at 900 (cited in note 88).

91479 US at 12. 
Court would focus on the optional nature of such proceedings, treat them as non-integral to the enforcement process of federally guaranteed rights, and thus deny fees. This section argues that such a result is unwarranted for two reasons. First, contrary to the Court's view, proceedings can be both optional as well as integral to an enforcement process. Second, awarding fees in the fair hearing context would reform the incentive structure so as to discourage needless litigation and improve local administration of AFDC.

\section{A. A Critique of the Optional/Non-optional Distinction}

Two views of administrative proceedings emerge from the Supreme Court cases regarding fee awards. One view, based on Title VII and articulated in Carey, sees administrative proceedings as playing an integral role in civil rights enforcement. Fees for such proceedings are allowed. Another view, based on statutes covered by $\S 1988$, such as $\S 1983$, sees administrative proceedings as largely unrelated to civil rights enforcement in federal court. This latter view was made explicit in $W e b b$.

The extent to which Webb forecloses fee awards for fair hearings depends on whether the Court's holding was based on a finding that the proceedings at issue in the case are not integral to enforcement of $\S 1983$ actions, or instead, that such proceedings are optional for the claimant who wishes to bring a $\$ 1983$ action in court. If the Court decided Webb on the basis of the non-integral nature of the proceedings, then the case can be read narrowly and confined to its facts. Its holding is then captured in the Court's statement that "[a]dministrative proceedings established to enforce tenure rights created by state law simply are not any part of the proceedings to enforce $\S 1983 .{ }^{\text {"92 }}$ Such a reading suggests that the holding in $W e b b$ would not foreclose attorney's fees for fair hearings. For, in contrast to the proceedings at issue in $W e b b$, fair hearings are part of a federal scheme of enforcing a federally guaranteed right. Though they are state run and optional, they are clearly also a forum for $\S 1983$ claims. The mere fact that a claimant is not required to exhaust the fair hearing remedy before going to court would not mean that the proceedings are governed by Webb.

In contrast, if the Court's holding relied primarily on the optional nature of the proceedings, then the role that they actually play in the enforcement of $\S 1983$ becomes irrelevant. All that mat- 
ters is that a claimant need not exhaust them before bringing a $\S$ 1983 action in federal court. This broad reading of Webb is captured in the Court's statement that "[b]ecause $\S 1983$ stands 'as an independent avenue of relief' and petitioner 'could go straight to court to assert it' the school board proceedings in this case simply do not have the same integral function under $\$ 1983$ that state administrative proceedings have under Title VII." ${ }^{\text {g3 }}$ If the Webb Court means to say that "optional" should always be read to mean "non-integral" then Webb must preclude an award of fees for work done in fair hearings as well.

Such a holding relies on the notion that in the absence of an exhaustion requirement, there is no evidence that Congress wished to encourage vindication of $\S 1983$ rights through administrative proceedings. ${ }^{94}$ But to focus on the initial congressional enforcement scheme of $\S 1983$ ignores the changes in $\S 1983$ litigation that have occurred since the Civil Rights Act of 1871 was passed. ${ }^{95}$ During the Reconstruction Era, when "the Federal Government was clearly established as a guarantor of the basic federal rights of individuals against incursions by state power," primary objectives was to provide citizens seeking redress from unconstitutional state action direct access to federal courts. This was one of the goals of $\S 1983$.

Since that time, state administrative agencies have taken a large role in implementing and enforcing federal statutes, ${ }^{97}$ and Thiboutot has extended $\S 1983$ to statutory claims. As a result, $\S$ 1983 now encompasses a large variety of claims that the 1871 Congress did not anticipate. ${ }^{98}$

Despite changes in $\S 1983$ litigation, the Court has continued to defer to the statute's historic goal of providing direct access to federal courts and has refused to require exhaustion of administrative or state court remedies. ${ }^{99}$ In Patsy $v$ Florida Board of Re-

${ }^{93}$ Id, citing Smith v Robinson, 468 US 992, 1011 n 14 (1984).

94 Id.

${ }^{93}$ Section 1 of that Act, 17 Stat 13, was the precursor of $\S 1983$.

96 Patsy o Florida Board of Regents, 457 US 496, 503-504 (1982).

${ }^{97}$ See the appendix to Justice Powell's dissent in Maine $v$ Thiboutot, 448 US at 34-37, listing a number of federal-state joint programs.

${ }^{\circ 8}$ See Patsy, 457 US at 507, where the Court notes that "the 1871 Congress . . . was [not] aware of the potential role of state administrative agencies."

99 Monroe v Pape, 365 US 167, 174-180 (1961) (overruled in part by Monell v Dept. of Social Services, 436 US 658 (1978)) (refusing to require exhaustion of state judicial remedies); McNeese v Board of Education, 373 US 668, 671 -73 (1963); and Patsy, 457 US at 500 516 (1982) (refusing to require exhaustion of state administrative remedies). In one instance, Congress has responded to these changes in $\S 1983$ litigation. In 1980, Congress passed 42 
gents, ${ }^{100}$ however, the Court voiced doubts about the continuing viability of non-exhaustion:

[T]here is serious disagreement over whether judicial or administrative procedures offer $\S 1983$ plaintiffs the swiftest, least costly, and most reliable remedy. . . . Similarly there is debate over whether the specialization of federal courts in constitutional law is more important than the specialization of administrative agencies in their areas of expertise, and over whether the symbolic and institutional function of federal courts in defining, legitimatizing, and enforcing constitutional claims outweighs the educational function that state and local agencies can serve. ${ }^{101}$

If the Court is right in suspecting that non-exhaustion is no longer viable, then it is hard to see how administrative proceedings such as fair hearings are "unrelated" to the enforcement of $\S 1983$. At the very least, optional proceedings and integral proceedings should not be treated as mutually exclusive.

\section{B. Combatting Incentives to Bypass Administrative Proceedings}

Aside from misapprehending the integral role that administrative proceedings play in enforcing $\S 1983$, the Court's current jurisprudence also creates two incentive problems. First, potential plaintiffs are encouraged to file suit in federal court even when administrative proceedings would be more suitable. Second, given the holding in Crest, a plaintiff who does decide to pursue optional administrative remedies has no incentive to resolve her dispute solely through administrative proceedings. She always has an incentive to file suit concurrently in federal court to preserve her right to attorney's fees in the event that she prevails on the administrative level. ${ }^{102}$ The Court in Crest indicated that even if all substantive claims are mooted by action on the administrative level, a

USC $\S 1997$ which creates a specific, limited exhaustion requirement for the largest class of $\S 1983$ claims, those brought by adult prisoners. Under $\S 1997 \mathrm{e}(\mathrm{b})$ the requirement of exhaustion is premised on the condition that state prisons develop adequate procedures for processing grievances.

100457 US 496 (1982).

${ }^{101}$ Id at $513 \mathrm{n} 15$.

${ }^{102}$ In such cases, the federal court may choose to abstain from ruling if the $\$ 1983$ claim is joined with a Fourteenth Amendment claim or a pendent state claim raising an unresolved issue of state law. This doctrine of abstention, known as Pullman abstention from Railroad Comm'n v Pullman Co., 312 US 496, 498 (1941), allows the state to resolve questions of state law and the federal court to avoid reaching constitutional questions unnecessarily. 
plaintiff may recover fees as long as she initially listed civil rights violations in her judicial complaint. ${ }^{103}$ Even courts that have denied fees have recognized this undesirable incentive, but have downplayed its importance. ${ }^{104}$

In both Webb and Crest, the Court emphasized that "[a]n interpretation of $\S 1988$ cannot be based on the assumption that 'an attorney would advise the client to forgo an available avenue of relief solely because $\S 1988$ does not provide for attorney's fees.' "106 The Court's reasoning ignores the purpose behind civil right's fee shifting statutes: such statutes are designed to create economic incentives for private enforcement of civil rights laws. While an attorney may not advise a client to forgo an avenue of relief, he or she may be reluctant to represent a client in administrative proceedings without any guarantee of receiving fees. ${ }^{106} \mathrm{~A}$ client who wishes to be represented may herself decide to forgo proceedings out of fear of being saddled with an otherwise avoidable bill for attorney's fees. Allowing recovery of attorney's fees for such proceedings would alleviate the problem of plaintiffs bringing actions in federal court to preserve their right to fees when a state administrative forum would be more appropriate for resolution of their complaint. ${ }^{107}$ If fees are available in both forums, attorneys and claimants will be able to choose the most appropriate forum based on the complexity of the case and the factors noted by the Court in Patsy without taking the availability of fees into account. $^{108}$

${ }^{103} 479$ US at $12-13$.

${ }^{10}$ See Blow v Lascaris, 523 F Supp 913, 917 (N D NY 1981), aff'd 668 F2d 670 (2d Cir 1982) (noting that the perverse incentives which result from denying fees to $\$ 1983$ plaintiffs for administrative proceedings may be compounded by Thiboutot since many federal statutory rights are left to state administrative bodies to implement); Webb, 471 US at $241 \mathrm{n} 15$.

${ }^{105}$ Crest, 479 US at 15 (quoting Webb, 471 US at $241 \mathrm{n} \mathrm{15).}$

${ }^{108}$ The Supreme Court realized this possibility in Evans $v$ Jeff D., 475 US 717 (1986) (upholding terms of settlement that required plaintiff to waive statutory right to assert subsequent claim for attorney's fees) where it noted "the possibility that decisions by individual clients to bargain away fee awards may, in the aggregate and in the long run, diminish lawyers' expectations of statutory fees in civil rights cases." As a result, "the pool of lawyers willing to represent plaintiffs in such cases might shrink." However, the Court believed that "as a practical matter the likelihood of this circumstance arising is remote." Id at 741-742 n 34.

${ }^{107}$ One of the important advantages of fair hearings is the speed with which claims are heard. Of the 28,040 fair hearing claims resolved in New York in fiscal year 1985, all but 790 were resolved in under 90 days. Quarterly Public Assistance Statistics, Requests for Fair Hearings in AFDC, U.S. Dept. of Health and Human Services 33 (Jan-March 1985) ("Quarterly Statistics").

${ }^{108}$ See text accompanying note 101. The Court's holding in Pennhurst State School \& Hosp. $v$ Halderman, 465 US 89, 97-124 (1984), may also make it more advantageous for 


\section{Improving the Quality of AFDC Administration}

Not only will allowing fees increase claimants' incentives to bring their claims in administrative proceedings, but liability for fees may act as an important check on the quality of local administration of AFDC. A recent report of the New York State Bar Association's Task Force on Administrative Adjudication found that "inadequacies at the local agency level are one of the major root causes for the huge caseload. Instead of properly handling client/ benefit issues at the caseworker level, a vast amount of cases are 'bounced upstairs' to a fair hearing as a means of resolving the problem." 109 The Task Force also found that after a fair hearing was requested, local agencies either withdrew their case action or were reversed by the Commissioner in the vast number of cases. ${ }^{110}$ It concluded that local agencies have no financial incentive to reduce the rate of error since no penalty is imposed for losing when a decision is challenged. In the meantime, "[ $t]$ housands of poor people are compelled to appeal to a state agency for relief from a local decision that the local agency knew or should have known was wrong." 111

The Task Force recommended that the state establish minimum affirmance standards that the local agencies would have to meet or else be subject to economic sanctions. Fee shifting can perform the same disciplinary function. The local government's knowledge that it will have to pay attorney's fees, at least when $\S$ 1983 claims are involved, ${ }^{112}$ may lead local officials to be more careful when denying or curtailing welfare funds.

One might argue that any money that the local government or state must pay for attorney's fees will decrease the amount it devotes to welfare payments. ${ }^{113}$ Such an argument is based on the

plaintiffs to advance claims in administrative proceedings. See note 42 .

${ }^{10}$ The New York State Bar Association, Report of the Task Force on Administrative Adjudication 175, (July 14, 1988) ("Task Force Report").

${ }^{110}$ New York City, for example, withdrew case actions or was reversed in 89 percent of the cases for which hearings were requested. Id at 176.

111 Id at 177.

112 It is important to remember that many fair hearings will not involve $\$ 1983$ claims. Of the cases that went to hearing in New York State, 61.8 percent involved the grant amount and of these, 84 percent involved claims under the state's need standard, and 38.2 percent of the claims involved unspecified "eligibility factors other than grant amount." Quarterly Statistics at 28, 32 (cited in note 107).

${ }^{13}$ A similar argument has been made by Jerry L. Mashaw against the procedural requirements mandated by the Court in Goldberg $v$ Kelly, 397 US 254, 266-71 (1970). Mashaw argues that the need for more funds to administer the system contemplated in Goldberg has resulted in agencies finding other ways to cut costs that are potentially more detrimental to 
questionable assumption that fee shifting will not decrease the state's error rate. For if that rate is in fact decreased, fewer termination decisions will be appealed, resulting in fewer fair hearings in the first place. This may well result in more money being available for welfare, not less.

\section{Attorney Participation in AFDC Proceedings}

Though reducing the number of erroneous determinations is laudable, one could argue that the current high rate of claimant success $^{114}$ despite low representation ${ }^{116}$ shows that claimants do not need attorneys in order to prevail. Studies conducted under the current system have in fact shown that the presence of counsel does not significantly increase a claimants chances of success. ${ }^{116}$ But commentators have surmised that this may be a result of claimants' use of attorneys who have "little or no experience in handling welfare appeals." 117 As one commentator noted in the context of social security disability claims, performance of counsel "occurs in the context of the incentive structure created by the existing system." 118 Attorneys' success rate might increase if attorneys were assured of fees, and, in time, a specialized bar for welfare claims might develop. ${ }^{110}$ Moreover, an active welfare bar would encourage appeals by recipients with legitimate claims who,

plaintiffs. Jerry L. Mashaw, Due Process in the Administrative State 33-34 (Yale, 1985).

${ }^{114}$ In 1985, claimants in New York State were successful in approximately 85 percent of the fair hearings held, prevailing in 22,784 out of 28,040 hearings. Quarterly Statistics at 31 (cited in note 107).

115 Only 974 of the 28,040 claimants who participated in New York State fair hearings in 1985 were represented by counsel. Id at 34 .

${ }^{116}$ Special Student Project, Procedural Due Process and the Welfare Recipient: A Statistical Study of AFDC Fair Hearings in Wisconsin, 1978 Wisc L Rev 145, 206, and Cooper, Goldberg's Forgotten Footnote, 64 Minn L Rev at 1170 (cited in note 24).

117 Id at $1170 \mathrm{n} 244$.

${ }^{118}$ Jerry L. Mashaw, et al, Social Security Hearings and Appeals: A Study of the Social Security Administration Hearing System 92 (Lexington, 1978). In the context of SSI hearings, Mashaw also noted: "The attorney's failure to devote time to the case, and a consequent unfamiliarity with the governing law or the facts concerning the claimant's condition, are repeatedly cited as characteristic of much legal representation." Id at 92.

210 If local officials improve their advocacy in fair hearings (a course urged by the Task Force Report), the claimant's need for an attorney may increase. The Task Force noted that at present "[m]ost of the applicants/recipients appear pro se and often are the persons least able to competently represent themselves, with many not having the ability to speak or write English, let alone the ability to comprehend the often technical requirements of the law governing their entitlement to public assistance." Task Force Report at 170-71 (cited in note 109). Such claimants, when faced with vigorous advocacy by local officials, may be in great need of an attorney. 
without an attorney, might not even be aware of their rights. ${ }^{120}$

On a practical level, one could argue that using attorneys will make the procedure more adversarial and time-consuming. Procedures designed to be short and non-combative will become full blown trials. The Supreme Court rejected this argument in Goldberg $v$ Kelly, where the Court noted that using attorneys would not necessarily encumber the hearing. ${ }^{121}$ More recently, however, in Walters $v$ Nat. Assn. of Radiation Survivors, the Court stressed the extent to which the presence of counsel may complicate otherwise simple procedures. ${ }^{122}$ In Radiation Survivors, the Court based its holding, in part, on a finding that Congress intended that the system of awarding veteran's benefits remain as informal and non-adversarial as possible. ${ }^{123}$

In the case of AFDC, however, HHS as well as the state of New York clearly contemplated the use of attorneys in fair hearings. The federal regulations and the state statute require that claimants be informed that they may be represented by counsel, ${ }^{124}$ and the state is responsible for travel expenses of claimant's counsel. ${ }^{125}$ In addition, the state statute requires that claimants be told of the availability of community legal services. ${ }^{126}$ Failure to provide this information to claimants constitutes grounds for annulling a hearing. ${ }^{127}$ Given these requirements, the concerns that the Court expressed in Radiation Survivors have little bearing on the use of attorneys in AFDC hearings.

120 That current claimants might be a self-selected group whose claims are obviously meritorious even to non-lawyers, might account for the very high success rate in fair hearings under the present system. See note 114.

121397 US 254, 270-271 (1970) (state termination of AFDC payments without prior evidentiary hearing violates Due Process Clause): "We do not say that counsel must be provided at the pre-termination hearing, but only that the recipient must be allowed to retain an attorney if he so desires. Counsel can help delineate the issues, present the factual contentions in an orderly manner, conduct cross-examination, and generally safeguard the interests of the recipient. We do not anticipate that this assistance will unduly prolong or otherwise encumber the hearing."

122473 US $305,324-326$ (1985) (upholding constitutionality of $\$ 10$ limitation on fee that may be paid an attorney or agent who represents a veteran seeking benefits for death or disability).

$123 \mathrm{Id}$ at 323.

12445 CFR $\S 205.10(a)(3)(i i i)$ (1987); NY Social Services Law, § 22(12)(c) (McKinney 1983).

${ }^{125}$ Monroe Cty. Legal Assist. Corp. v Lavine, 82 Misc 2d 343, 368 NYS2d 1008 (Sup Ct 1975).

${ }^{126}$ NY Social Services Law, $§ 22(12)(d)$ (McKinney 1983).

${ }^{127}$ Breitfeller v D'Elia, 99 App Div 2d 756, 471 NYS2d 663 (1984). 


\section{A Critique of the Court's Reasoning in Crest}

The preceding section has argued that attorney's fees should be awarded for successful $\S 1983$ claims in AFDC proceedings, both as a means of encouraging greater use of the proceedings and as a means of curtailing erroneous decisions by local officials. In other words, despite the fact that the proceedings are optional, the Court should analogize them to Title VII proceedings and not to the proceedings at issue in $W e b b$. But $W e b b$ is not the only decision that stands in the way of fee awards. Under the Court's decision in Crest, a claimant who prevails in administrative proceedings and is not required to bring a court action on the merits is barred from bringing a separate action for fees under $\S 1988$.

\section{A. The Relationship Between Crest and Carey}

The decision in Crest seems to run directly counter to the decision in New York Gaslight Club, Inc. $v$ Carey, where the Supreme Court upheld an award of fees under Title VII upon finding that Title VII supports "a suit solely to obtain an award of attorney's fees for legal work done in state and local proceedings." $128 \mathrm{~A}$ federal action solely for fees, albeit in the context of $\S 1988$, is precisely what confronted the Court in Crest. The Crest Court avoided overruling Carey by treating its case as one of first impression and reading Carey as having reached the issue of an independent action for fees only in dicta. ${ }^{129}$

This characterization of Carey is not convincing. First, both the majority and dissent at the appellate level in Carey understood the case as involving a separate action solely for fees. ${ }^{130}$ Justice Blackmun, writing for five justices in Carey, also understood the facts of the case to require the Court to reach the question that the Crest Court characterizes as dicta. ${ }^{131}$ Second, two years after $\mathrm{Ca}$ -

${ }^{128} 447$ US at 66.

129479 US at 13-14. The Crest court points to Justice Stevens' concurrence in Carey where he writes that "[w] hether Congress intended to authorize a separate federal action solely to recover costs, including attorney's fees, incurred in obtaining administrative relief in either a deferral or a nondeferral State is not only doubtful but is a question that is plainly not presented by this record." 447 US at 71 . In Carey, Stevens pointed out that respondent's initial complaint in federal court did include substantive civil rights claims. For the purposes of characterizing the attorney's fee claim in Carey, Stevens found it irrelevant that all substantive claims were dismissed by agreement between the parties before any action was taken on them by the federal court. Id at 71-72.

${ }^{230}$ Carey v New York Gaslight Club, Inc., 598 F2d 1253, 1255-56 (2d Cir 1979).

131 Blackmun's understanding is not difficult to defend. In Carey, the federal court action was filed with the understanding that its substantive claims would only be pursued if 
rey, the Supreme Court itself cited the case for the proposition that Title VII will "support a federal suit 'solely to obtain an award of attorney's fees for legal work done in state and local proceedings." "132 Third, the legislative history surrounding the 1986 passage of the Handicapped Children's Protection Act of 1986 ("HCPA"), ${ }^{133}$ which provides attorneys fees for plaintiffs who prevail in actions brought under the Education of the Handicapped Act, ("EHA"), ${ }^{134}$ demonstrates both that Congress understood $\mathrm{Ca}$ rey to reach the question of fee awards for administrative proceedings, and that Congress approved of the Carey holding. ${ }^{136}$ Courts that have ruled on the availability of attorney's fees in a separate suit under the HCPA have found that the Crest ruling does not operate to disallow fee recovery, since Congress clearly intended Carey to control the outcome. ${ }^{136}$ Finally, in Jones $v$ American State Bank, ${ }^{137}$ the Eighth Circuit recently allowed a Title VII plaintiff to bring a separate action for fees, finding that even after Crest, Carey continues to control such actions in Title VII cases and allows for $\dot{a}$ separate action.

In the context of Title VII, the Court recognized in Carey that if plaintiffs are required to participate in administrative proceedings it would be unfair to deny them fees for such proceedings. It

the plaintiff did not prevail at the administrative level. Since Carey had already prevailed at the administrative level and had no reason to request relief on the substantive counts, the only issue before the district court was the award of attorney's fees for prior success at the administrative level. What distinguished Carey as a case of "first impression," id at 1255, was that federal court litigation was not necessary to vindicate the respondent's Title VII rights since she had already prevailed through administrative channels.

${ }^{132}$ White v New Hampshire Dept. of Empl. Sec., 455 US 445, 452 n 13 (1982).

13s Pub L No 99-372, 100 Stat 796, codified at 20 USCA § 1415 (Supp 1988).

134 20 USC $\S 1400$ et seq (1982).

135 The HCPA was passed after the Court's decisions in Carey and Webb, but before the Crest decision. In the HCPA, Congress specified that the fee shifting provision included the award of fees to plaintiffs who prevail in administrative proceedings. 20 USCA § 1415(e)(4)(D)(i) and (iii) (Supp 1988). The Congressional debates surrounding passage of the Act and the Report of the Senate Labor and Human Resources Committee, S Rep No 112, 99th Cong, 2d Sess, reprinted in 1986 USCCAN 1798, suggest that Congress relied on Carey as providing the precedent for such an award. See, for example, 131 Cong Rec No 104, S10400 (July 30, 1985) (Sen. Simon on Carey); 131 Cong Rec No 155, H9969-9970 (Nov 12, 1985) (Rep. Williams, Rep. Biaggi). But see 131 Cong Rec No 155, H9966-9967 (Nov 12, 1985) (Rep. Bartlett); 132 Cong Rec No 97, H4842 (Rep. Bartlett); and id at H4844 (Rep. Jeffords) (July 24, 1986).

136 Three courts specifically mention Crest: Prescott $v$ Palos Verdes Peninsula Unified Sch., 659 F Supp 921, 924 n 3 (D C Cal 1987); Burpee v Manchester School Dist., 661 F Supp 731, 733 (D NH 1987); and Michael F. v Cambridge School Department, No 86-2532C, 1987 WL 7752 (D Mass March 5, 1987). But see Rollison v Biggs, 660 F Supp 875, 877 (D Del 1987).

${ }^{137}$ No 87-5480, 1988 USAPP LEXIS 12893 (8th Cir Sept 21, 1988). 
also recognized that it would be anomalous to deny fees to plaintiffs who prevail in such proceedings, but to award them to plaintiffs who are unsuccessful before state fair employment practice agencies but ultimately vindicate their rights in federal court. For these reasons, it allowed a separate action for fees.

In Crest, however, the Court barred plaintiffs with fee claims under $\S 1988$ from bringing a separate action for fees even if the administrative proceeding in which they prevailed clearly concerned a $\S 1983$ claim. The Court once again distinguished, as it had in $W e b b$, proceedings that are mandatory under Title VII from those that are optional under $\S 1988$. It suggested that in the absence of an exhaustion requirement, it is unclear what types of administrative proceedings actually enforce the various statutes listed in $\S 1988$. In order to identify when a claim is truly a civil rights action, one needs a bright line rule. The Court decided that the filing of a complaint on the merits affords such a bright line.

\section{B. The Language and Purpose of $\S 1988$}

The Court's decision in Crest to use the filing of a judicial complaint to differentiate between plaintiffs who may recover fees for administrative proceedings under $\S 1988$ and those who may not, does not follow from the language of the statute ${ }^{198}$ or from its legislative history. The Supreme Court has cited the terminology of the House Report accompanying $\S 1988$ to support the proposition that Congress "clearly contemplated that parties obtaining fees would have initiated civil rights litigation." that the House Report refers to "the litigation," "out-of-court settlement," and the filing of the "complaint."140 This language may justify the conclusion that Congress thought most fee recoveries would follow court actions, but it does not demonstrate that fee recovery for administrative proceedings falls outside the scope $\S$ 1988.

The Court also concluded that "an award of attorney's fees under $\S 1988$ depends not only on the results obtained, but also on what actions were needed to achieve those results."141 However, the legislative history, as it emerges from the committee reports, shows that Congress was much more concerned with the outcome

${ }^{138}$ The language of $\S 1988$ is the same as Title VII which, the Court has found, does support an award of fees in an independent action. See section II.A.

${ }^{139}$ Crest, 479 US at 13.

140 Id at 12-13; See also, Webb, 471 US at 241 n 16.

141479 US at $12-13$. 
of the actions (that they result in the vindication of rights protected by civil rights statutes) than with the type of procedure used to effect this outcome. In an effort to make sure that attorney's fees would not be limited to suits that are fully adjudicated on the merits, the House Report states that an order need not be final, only that it must "determin[e] substantial rights of the parties" to make award of attorney's fees appropriate. ${ }^{142}$

To illustrate this point, the House Report notes that a settlement or a consent decree between the parties not only provides an acceptable basis for a fee award but that such resolutions should be encouraged as they help lessen docket congestion. ${ }^{143}$ In addition, as noted in section I of this comment, the committee also intended that fees be available to parties who prevail on pendent state claims when there are statutory fee claims or constitutional fee claims that are not reached but that arose out of a "common nucleus of operative fact" with the fee claim. ${ }^{144}$ Finally, claims that are moot because the defendant has voluntarily ceased the unlawful practice may also merit an award of fees. ${ }^{145}$

The various situations mentioned in the House Report have provided the basis for fee awards in cases following passage of $\S$ 1988. Plaintiffs have been awarded attorney's fees when the suit is resolved by settlement or a consent decree, ${ }^{146}$ when a plaintiff prevails on pendent non-fee claims, ${ }^{147}$ or when a plaintiff's suit has been rendered moot because of some voluntary act of the defendant. ${ }^{148}$

${ }^{142}$ House Report at 8, reprinted in Source Book at 216 (cited in note 37).

${ }^{143}$ Id at 7, reprinted in Source Book at 215 (cited in note 37).

144 Id at $4 \mathrm{n} 7$, reprinted in Source Book at 212 (cited in note 37).

145 "Similarly, after a complaint is filed, a defendant might voluntarily cease the unlawful practice. A court should still award fees even though it might conclude, as a matter of equity, that no formal relief, such as an injunction, is needed." Id at 7, reprinted in Source Book at 215. See also, Comment, Civil Rights Attorney's Fees Awards in Moot Cases, 49 U Chi L Rev 819 (1982).

${ }^{118}$ Maher v Gagne, 448 US 122, 129 (1980) ( $\$ 1983$ challenge to state's AFDC regulations): "The fact that respondent prevailed through a settlement rather than through litigation does not weaken her claim to fees. Nothing in the language of $\S 1988$ conditions the District Court's power to award fees on full litigation of the issues or on a judicial determination that the plaintiff's rights have been violated."

147 Carreras $v$ City of Anaheim, 768 F2d 1039, 1050 (9th Cir 1985) (when the plaintiff in a civil rights action prevails on a pendent state claim based on the same nucleus of operative fact as a substantial federal claim, fees may be awarded under $\S 1988$ ).

148 Martin v Heckler, 773 F2d 1145, 1149 (11th Cir 1985) (en banc), citing Robinson v Kimbrough, 652 F2d 458, 465 (5th Cir 1981) (plaintiffs will be awarded fees even though claim mooted if " 'plaintiffs' lawsuit was a catalyst motivating defendants to provide the primary relief sought in a manner desired by litigation' "). See also, Williams v Miller, 620 F2d 199 (8th Cir 1980). 
As the Court points out in Crest, the cases that the House Report cites in support of the above propositions included at least the filing of a judicial complaint. ${ }^{149}$ However, a case in which the plaintiff has obtained final relief without a judgment seems no closer to a "true" court action than one in which she obtained relief through administrative proceedings undertaken pursuant to federal statute. The determination of a plaintiff's rights by an administrative agency after a full evidentiary hearing may provide a better record on which to base attorney's fees than a case resolved through settlement.

\section{The Anomaly Arising from Crest}

$W e b b$ clearly allowed fees for at least some work in optional administrative proceedings that culminate in court actions. Therefore, the Crest ruling gives rise to a weaker form of the anomaly already anticipated in dicta of Parker $v$ Califano, one of the earliest Title VII cases: A plaintiff" "who is unsuccessful in the administrative proceedings but succeeds in court will be able to recoup attorneys' fees for all legal services rendered, while a plaintiff who is successful at the administrative level will not be able to recoup any attorneys' fees."160 In Parker, it was the defendant who pointed out this anomaly in arguing against the award of fees even for administrative proceedings that do culminate in court actions. The court, however, while stressing that the question was not before it, suggested that one way to solve this problem would be "to allow the plaintiff to come to court on the single issue of whether, and in what amount, attorneys' fees are to be awarded."151 This is precisely the solution that the Court rejected in Crest.

In other early cases, courts dismissed similar arguments made by defendants opposing fee requests either by pointing to Parker's suggested solution to the anomaly ${ }^{\mathbf{1 6 2}}$ or by deciding that an agency itself could be given the authority to award fees. ${ }^{153}$ Still other courts have noted the anomaly that results from denying fees for successful administrative proceedings, but have denied fees anyway. ${ }^{154}$ In Carey, the Supreme Court's decision to award fees was

14979 US at 13.

${ }^{250}$ Parker v Califano, 561 F2d 320, 330 n 24 (DC Cir 1977).

181 Id.

${ }^{152}$ Foster $v$ Boorstin, 561 F2d 340, 343 n 8 (DC Cir 1977); Fischer v Adams, 572 F2d 406, 410 (1st Cir 1978).

${ }^{153}$ Smith v Califano, 446 F Supp 530, 532 n 3 (D DC 1978).

154 Derheim v Hennepin Cty. Bur. of Soc. Serv., Etc., 524 F Supp 1321, 1324 n 2 (D Minn 1981) (arguing that anomaly will be less of a danger in a $\S 1983$ suit than in a Title 
based in part on a recognition of the anomaly that would result from a denial of fees. The court of appeals in Crest followed this reasoning, ${ }^{165}$ but the Supreme Court dealt with the problem simply by stating that ". . . if one must ignore the plain language of a statute to avoid a possible anomalous result ' $[t]$ he short answer is that Congress did not write the statute that way.' "156

\section{The Crest Court's Concerns and AFDC Fair Hearings.}

In Crest, the Court held that a plaintiff may not request fees unless she has filed a complaint on the merits of her case as well. The Court's decision to adopt this rule points to a policy concern that may have been driving the opinion itself: the concern that allowing separate actions for fees will open up too many out-of-court activities to fee requests. ${ }^{157}$ The Court assumes that since optional administrative proceedings may be much more informal than court actions, it will be impossible to judge which proceedings deserve attorney's fees. Once "proceedings" is read too broadly, all sorts of informal negotiations may give rise to fee requests. To show the absurdity of allowing fees for out-of-court proceedings, the majority conjures up a world in which attorney's fees must be awarded when an employee, after talking to his lawyer, informally discusses hiring or promotion practices with an employer, who in response alters those practices to comply more fully with employment discrimination laws. ${ }^{188}$

The majority's concerns are not entirely convincing when viewed in the context of the Title VI negotiations in Crest, but they become even less persuasive when the proceedings at issue are the much more formal fair hearings under the Social Security Act. In the context of such proceedings, the "legitimacy" rational for requiring a complaint on the merits does not apply. The plaintiff has already been required to undertake quasi-judicial action to vindicate her rights. The filing of a complaint on the merits cannot increase the legitimacy of the plaintiff's actions. There is no need for a bright line rule that separates "true" actions from informal

VII action since it is more likely that the content of $\S 1983$ administrative proceedings will diverge from the content of $\S 1983$ suit. Therefore, "[a] plaintiff with a strong case before an administrative body may have a very weak section 1983 claim."); Blow, 523 F Supp at 917 (noting anomaly but finding its remedy more properly the task of the federal legislature).

${ }^{13 s}$ Crest Street Community Council, Inc. v N.C. Dept. of Transp., 769 F2d 1025, 1033

(4th Cir 1985).

${ }^{188} 479$ US at 14 (quoting Garcia v United States, 469 US 70, 79 (1984)).

257479 US at 14.

${ }^{168}$ Id. 
discussions.

\section{E. A Congressional Solution}

Given the categorical nature of the decision in Crest that $\S$ 1988 does not allow a separate action solely for fees, it is unlikely that the Court will make an exception and allow plaintiffs who prevail on $\S 1983$ claims in fair hearings to bring separate actions for fees. In the past, Congress has traditionally taken the lead in responding to the Court's decisions concerning attorney's fees. The 1976 Attorney's Fees Awards Act was passed in response to the Court's decision in Alyeska Pipeline Co. $v$ Wilderness Society, ${ }^{159}$ holding that, absent statutory authorization, attorney's fees may not be awarded in civil rights actions. The attorney's fee provision accompanying the Education of the Handicapped Act was passed in response to the Court's decision in Smith $v$ Robinson ${ }^{\mathbf{1 6 0}}$ denying plaintiff's who prevailed under that Act from receiving attorney's fees under $\S 1988$ or under the fee shifting provisions of the Rehabilitation Act. ${ }^{161}$

One court has already appealed to Congress to clarify the law governing attorney's fees for administrative proceedings to enforce $\S 1983$. In Blow v Lascaris, ${ }^{162}$ a case involving a fair hearing under AFDC, the district court agreed that the plaintiff had in fact prevailed in an administrative proceeding to enforce a federal statutory right protected by $\S 1983$. Therefore, it only examined the question of whether $\S 1988$ allowed an independent action for fees. ${ }^{163}$ The court concluded that such an action was procedurally barred, but expressed misgivings about the possibly unfair results of its decision. It appealed to Congress to remedy the problem:

Since many federal statutory rights, such as the one involved in the present case, are left to state administrative bodies to implement, it seems probable that the frequency of cases with factual patterns similar or identical to the present case will increase. While this Court's construction of $\S 1988$ embodied

\footnotetext{
189 421 US 240 (1975).

160468 US 992 (1984). See note 52.

16129 USC § 794a (1982).

162523 F Supp 913 (N D NY 1981), aff'd 668 F2d 670 (2d Cir 1982).

1es One article written before the Court's decisions in Webb and Crest used this case to argue that fees should be awarded to plaintiffs who prevail in administrative proceedings. Though Justice Brennan cited to the article in his dissent in Crest, the author's plea was not effective. See Jeffrey A. Parness and Gigi A. Woodruff, Federal District Court Proceedings to Recover Attorney's Fees for Prevailing Parties on Section 1983 Claims in State Administrative Agencies, $18 \mathrm{Ga} \mathrm{L}$ Rev 83 (1983).
} 
in this decision may well be burdensome and onerous to both litigants and the federal courts ... [t] the task of clarifying the proper scope of [ $\S 1988]$. . . is more properly left to the federal legislature." 164

Congress has not yet responded to the court's appeal.

In order to overturn the application of Crest to fair hearings, Congress should amend the Social Security Act ${ }^{165}$ to provide that fees shall be available under $\S 1988$ for claimants who prevail in administrative fair hearings on claims that state a cause of action under $\S 1983$. Such an amendment would be consistent with the language of $\S 1988$ and would encourage claimants to use these hearings instead of filing suit in federal court.

\section{Conclusion}

Allowing recovery of attorney's fees for successful actions brought under $\S 1983$ encourages private citizens to take an active role in enforcing their federally guaranteed rights. Court actions provide only one means of enforcing such rights. In addition, administrative enforcement mechanisms such as fair hearings allow individuals to present $\S 1983$ claims in a quasi-judicial setting before state agencies.

Individuals who wish to contest a denial of welfare benefits in fair hearings are told that they have the right to be represented by an attorney. However, under current law they cannot recover attorney's fees under $\S 1988$ if they prevail on $\S 1983$ claims raised in such hearings, though identical claims would provide the basis for a fee award in state or federal court. As a result, individuals with $\S$ 1983 claims have an incentive to bypass administrative remedies and file court actions in order to preserve their right to attorney's fees under $\S 1988$.

184 523 F Supp at 917.

${ }^{165}$ If Congress amended the Social Security Act, fees would also be available for fair hearings conducted under the Medicaid program, 42 USC $\$ 1396$ et seq, the administrative procedures of which are essentially the same as those governing the AFDC program. See 42 CFR \& 431.201 et seq (1987). A separate amendment would be needed to provide fees for plaintiffs who prevail in hearings held under the Food Stamp Act of 1977, 7 USC $\S 2011$ et seq (1982), the procedures of which are set forth in 7 CFR $\$ \S 273.15,277.16$ (1987).

It is likely that a small but significant percentage of fair hearings under these statutes will also involve issues of federal law and give rise to $\S 1983$ claims. In an article in August of 1988, the New York Times reported that of the fair hearings held to contest decisions made by New York City (including food stamps, Medicaid, and state welfare appeals), 6.7 percent of the cases the city lost involved situations in which a law, regulation, or policy was misapplied. Josh Barbanel, Welfare in New York: Judging System's Errors, NY Times at 11 (Aug 29, 1988). 
This comment has argued that in a limited class of hearings, which can be characterized as "proceedings to enforce $\S 1983$," fees should be awarded to prevailing parties-whether those parties prevail only after judicial action or in the administrative hearings themselves. Congress should amend the Social Security Act, specifically rejecting application of the Supreme Court's decisions in $W e b b$ and Crest to fair hearings conducted pursuant to that Act. By allowing fees under $\S 1988$ for fair hearings, Congress will encourage the use of administrative remedies and distribute welfarebased $\S 1983$ actions more evenly between agencies and the courts. 
